\title{
The Effect of Environmental Factors on the Event of Acute Diarrhea
}

\author{
Gita Sekar Prihanti, Syuna Salimdra, Muhammad Ilham Akbar, Muhammad Gagas Sasongko, \\ Syafira Amelia Amir
}

\begin{abstract}
Diarrhea is an environment-based disease endemic in Indonesia with a high prevalence rate resulted from contaminated dug wells. From this study, we want to know the influence of environmental factors, namely microbiology of water, clean water facilities (CWF), toilet facilities and sewerage facilities (SF) and the availability of trash bins against the incidence of acute diarrhea. We used cross sectional observational analytic study with a total of 228 users of dug wells and 38 dug wells that met the inclusion criteria in the Community Health Center. We used questionnaires and checklists to collect data of variables CWF, latrine, SF and availability of trash bins also laboratory results from the Kediri Regional Health Laboratory for water microbiology. We analyzed the data by Chi square test and Linear Regression and the bivariate test results showed that water microbiological factors $p=0,000, C W F p=0,000$, toilet facilities $p=0,001$ and $S F p=0,005$ which significantly affected the incidence of diarrhea. The multivariate test results showed that water microbiological factors had the most significant effect on the incidence of diarrhea ( $p=0,000 ;$ OR: 4,67; 95\% CI: 2,51 - 8,7). The need for counseling interventions as well as improving the quality of well water and CWF by improving well construction, checking well water regularly and cooking well water before consumption. There exist a need to form a closed, permanent and non-stagnant $S F$ and the construction of clean toilets, non-soil floors and a distance of septic tanks >10m from CWF.
\end{abstract}

Keywords: Clean water facilities, diarrhea, dug wells, latrines, waste water disposal facilities.

\section{INTRODUCTION}

Diarrhea is defined as part of three or more runny stools or a number of stools that are formless or flabby in 24 hour period, with or without one of the following symptoms: fever, abdominal pain or cramps, nausea and vomiting. In 2016, diarrhea was the eighth leading cause of death among all ages and the fifth was the leading cause of death among children under 5 deaths occur in children under 5 years, and around $90 \%(89,37 \%)$ of diarrhea deaths occur in southern Asia and sub-Saharan Africa [1].

Diarrhea is an environment-based disease [2]. Many risk factors are thought to cause diarrheal disease. One of the factors

\footnotetext{
Revised Manuscript Received on January, 2020.

* Correspondence Author

Gita Sekar Prihanti*, Lecturer of Faculty of Medicine, University of Muhammadiyah Malang, Malang, Indonesia. Email: gitasekarprihanti@gmail.com

Syuna Salimdra Instructur of Faculty of Medicine, University of Muhammadiyah Malang, Malang, Indonesia. Email: syunasalimdra@gmail.com

Muhammad Ilham Akbar, Muhammad Gagas Sasongko, Syafira Amelia Amir, Instructur of Faculty of Medicine, University of Muhammadiyah Malang, Malang, Indonesia.
}

is poor environmental sanitation, unhygienic water supply, and lack of knowledge [3]. Safe and healthy water is a basic requirement for good health [4]. Water sources in low-income countries and rural areas are at risk of contamination [5].

The main cause of waterborne diseases is microbiological contamination [6]. Water microbiological contamination is responsible for most waterborne diseases, especially diarrhea [4]. Microbiological contamination of water can be caused by bacteria, protozoa, viruses and fungi that mostly originate from waste disposal and other human activities [7]. The most bacteria in contaminated water are E. coli, Salmonella sp., Shigella sp., Campylobacter sp. E. Coli is the most found bacterium that causes diarrhea [8]. Fecal contamination has been detected in groundwater sources in various developed and developing countries.

Based on recent studies in Bangladesh, $65 \%$ of dug wells contain faeces / thermotolerant coliforms and Escherichia coli (E. coli) that were some of the indicators of contamination of faeces. Possible mechanisms for contamination are infiltration of the contaminant from nearby latrines, septic tanks, and ponds into groundwater aquifers, the connection of short-flow contaminated surface water into wells through unsealed well components, or accumulation of bacteria in water pumps that contaminated [9]. Microbiological examination of water can determine whether the water is contaminated or not so that it can help determine actions in the prevention of diarrhea such as through counseling about water treatment before consumption [10].

\section{METHODS}

This study was analytic observational with a cross sectional study design. This research was conducted in the $\mathrm{K}$ City. The total sample of this study were 228 dug well users who had diarrhea and no diarrhea during December 2018 to February 2019. The sampling technique that used in this research was simple random sampling.

The dependent variable in this study was the incidence of diarrhea in all age groups of users of dug wells while the independent variables in this study are microbiological levels of dug well water, clean water facilities, family toilet facilities, sewerage facilities, garbage disposal facilities.

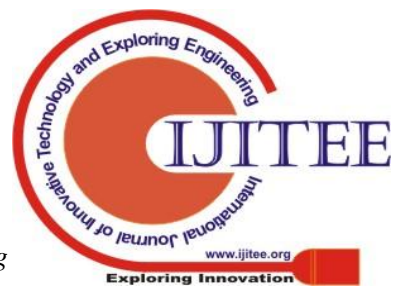


Testing of water for the number of Coli group bacteria is carried out in several levels, namely: approximate testing, affirmation testing, and complete testing. How to calculate the Nearest Probable Number (MPN) Approximate Amount (JPT). The positive number of tubes from the assay of the assertion assumption and complete testing of the coli group testing of the double tube procedure is a combination and stated in terms of MPN or JPT.

\section{RESULTS}

\section{A. Univariate analysis of Characteristics of Respondents Based Microbiology Air, Clean Water, Toilet Facilities, SF, Trash}

Based on table 1, the respondent obtained by simple random sampling number of 228 respondents, of which 72 (31.6\%) had suffered from diarrhea in the last 3 months and $156(68.4 \%)$ do not suffer from diarrhea in the last 3 months. The respondent who had the microbiology result is good was $112(49,1 \%)$ and the respondent who had the water microbiology is not eligible was $116(50,9 \%)$. The respondent who had the quality of clean water result is good was $116(50,9 \%)$ and the respondent who had the clean water was not eligible is $112(49,1 \%)$. The respondent who had the quality of means latrine result is good was $101(44,3 \%)$ and the respondent who had the means latrine was not eligible is $127(55,7 \%)$. The respondent who had the quality of means SF result is good was $123(53,9 \%)$ and the respondent who had the means SF was not eligible is $105(46,1 \%)$. The respondent who had the quality of means trash result is good was $135(57,9 \%)$ and the respondent who had the means SF was not eligible is $96(42,1 \%)$.

\section{A. Bivariate Analysis Relationship Between Water Microbiology factor, CWF, toilet and Means Means SF with Genesis Diarrhea}

The data analysis in table 2 showed that there is a correlation between microbiological water means clean water, toilet facilities and means SF against diarrhea while means trash showed no relationship to the incidence of diarrhea in the wells in Public Health Center of Northern Territory Town of Kediri. Relationships water microbiology laboratory results on the incidence of diarrhea has a significant value of $p(0.000)$. Clean water facilities have been associated with diarrhea with significant value of $p$ (0.000). Latrines have been associated with diarrhea with significant value of $\mathrm{p}(0.000)$. SF has been associated with diarrhea with significant value of $p(0.005)$. Means bins have significant value of $\mathrm{p}(0.176)$ on the incidence of diarrhea.

\section{B. Multivariate Analysis Relationship Between Water Microbiology factor, CWF, toilet and Means Means SF with Genesis Diarrhea}

Multivariate analysis of factors affecting the incidence of diarrhea in the wells in Public Health Center of Northern Territory town of Kediri using logistic regression as the table below.From table 3 noted that the variables that had a p-value $<0.05$ was water microbiology. Microbiology of water has a sig. $=0.000$ which means the respondent with the results of microbiological underground water in wells that do not qualify have an influence on the incidence of diarrhea in Public Health Center of Northern Territory town of Kediri. Value OR (odds ratio) obtained is 4.67 meaning that the possibility of diarrhea in the wells with underground water microbiology results that do not qualify higher diarrhea 4.67 time the wells with underground water microbiology results that qualify, Because OR> 1 can also be said the wells with underground water microbiology results that do not qualify higher chance against diarrhea.

Table- I: Result of Univariate Analysis of Characteristics of Respondents

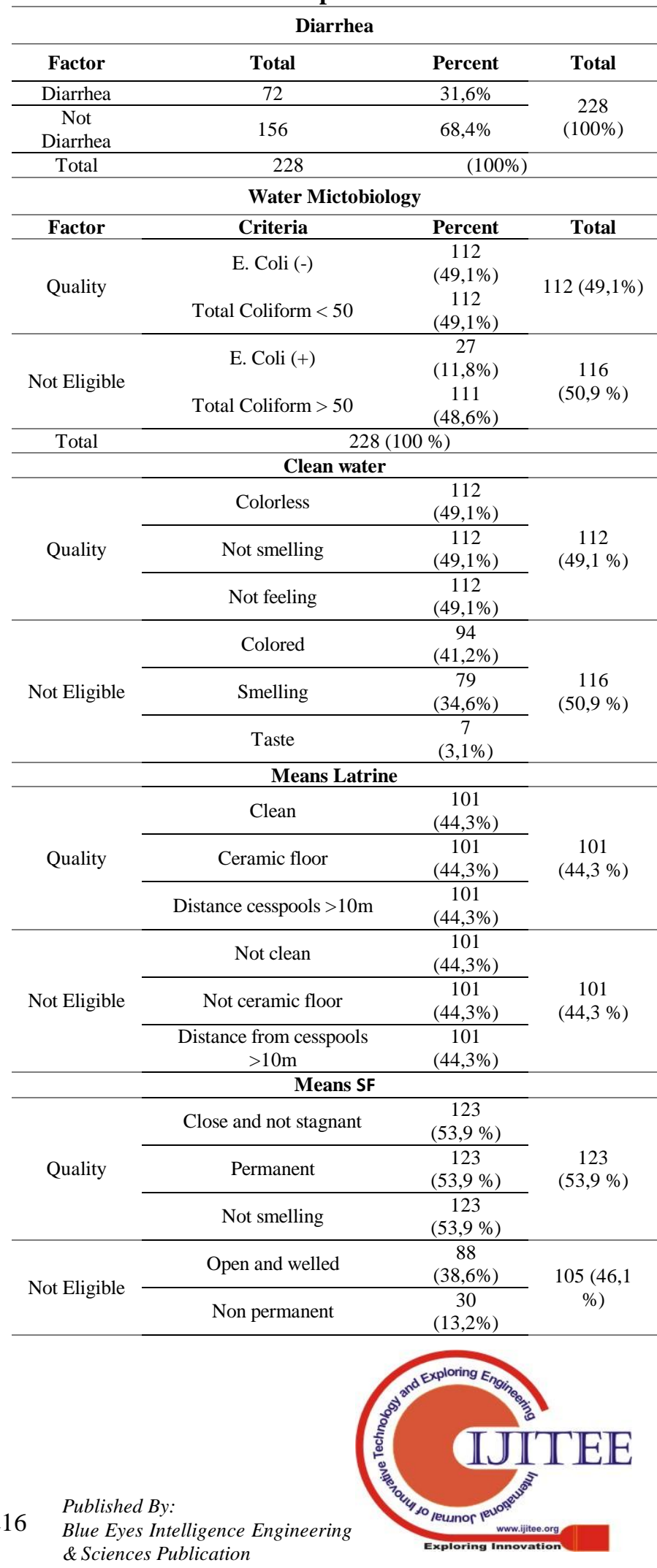




\begin{tabular}{|c|c|c|c|}
\hline & No Odor & $\begin{array}{c}76 \\
(33,3 \%) \\
\end{array}$ & \\
\hline \multicolumn{4}{|c|}{ Means Trash } \\
\hline \multirow{3}{*}{ Quality } & Close & $\begin{array}{c}135 \\
(57,9 \%) \\
\end{array}$ & \multirow{3}{*}{$\begin{array}{c}135 \\
(57,9 \%)\end{array}$} \\
\hline & Waterproof & $\begin{array}{c}135 \\
(57,9 \%)\end{array}$ & \\
\hline & Not strewn & $\begin{array}{c}135 \\
(57,9 \%)\end{array}$ & \\
\hline \multirow{2}{*}{ Not Eligible } & Open & $\begin{array}{c}79 \\
(34,6 \%) \\
\end{array}$ & \multirow{2}{*}{$\begin{array}{c}96 \\
(42,1 \%)\end{array}$} \\
\hline & Not waterproof & $\begin{array}{c}79 \\
(34,6 \%) \\
\end{array}$ & \\
\hline
\end{tabular}

Strewn $\begin{gathered}64 \\ (28,1 \%)\end{gathered}$
Well users with water microbiology results that do not qualify
chance of diarrhea by $47 \%$. Users wells with water microbiology
results were eligible likely to occur diarrhea by $18.7 \%$. From
Wald test results are known only one significant variable,
namely microbiological water so that when used as a percentage
of $10.9 \%$ (Cox \& Snell R Square) effect on the incidence of
diarrhea.

Table- II: Result of The Bivariate Analysis

\begin{tabular}{|c|c|c|c|c|c|}
\hline \multirow[b]{2}{*}{ Factor } & \multirow[b]{2}{*}{ Criteria } & \multicolumn{2}{|c|}{ Diarrhea } & \multirow[b]{2}{*}{ Total } & \multirow[b]{2}{*}{$\mathbf{P}$} \\
\hline & & No diarrhea & Diarrhea & & \\
\hline \multirow{2}{*}{ Clean Water } & Qualify & $83.9 \%$ & $16.1 \%$ & $100 \%$ & \multirow{2}{*}{0000} \\
\hline & Not eligible & $53.4 \%$ & $46.6 \%$ & $100 \%$ & \\
\hline \multirow{2}{*}{ Means Latrine } & Qualify & $832 \%$ & $16.8 \%$ & $100 \%$ & \multirow{2}{*}{0000} \\
\hline & Not eligible & $56.7 \%$ & $43.3 \%$ & $100 \%$ & \\
\hline \multirow{2}{*}{ Means SF } & Qualify & $76.4 \%$ & $23.6 \%$ & $100 \%$ & \multirow{2}{*}{0005} \\
\hline & Not eligible & $59 \%$ & $41 \%$ & $100 \%$ & \\
\hline \multirow{2}{*}{ Means Trash } & Qualify & $72 \%$ & $28 \%$ & $100 \%$ & \multirow{2}{*}{0176} \\
\hline & Not eligible & $63.5 \%$ & $36.5 \%$ & $100 \%$ & \\
\hline $\begin{array}{c}\text { Microbiological } \\
\text { Groundwater At the Well } \\
\text { Drilling }\end{array}$ & Qualify & $84.1 \%$ & $15.9 \%$ & $100 \%$ & 0000 \\
\hline
\end{tabular}

\section{DISCUSSION}

In this study, a microbiology of underground water digs, clean water facilities, SF facilities and the ownership of latrine had a significant incidence of diarrhea ( $p$ value $<0.005)$ while the disposal garbage had not a significant effect to diarrhea incidence ( $\mathrm{p}$ value 0.316 ) at the working area of the public health centre in the northern territory of the city of Kediri.

Diarrhea can be caused by contaminating water in dugs well who provides water that comes from the soil layer which is relatively close from ground level, therefore it can be easily to contamination through seepage. The seepage can comes from a place for human latrines or toilets and animal waste. The seepage also can be from well waste itself.

Research by Rasako said that there was a significant influence between the quality of water microbiology and the incidence of diarrhea. This can be caused by contamination of dug well water from an adjacent distance (less than $10 \mathrm{~m}$ ) with septic tanks found in 155 respondents. The distance of the septic tank adjacent to dig well is polluted by the Escherichia coli water due to the limited land area, and the construction of septic tanks that are not airtight, as well as porosity, the permeability of the soil that can be accessed by infiltration according to the needs caused by bacteria [11].

Research by Asnel and Sari 2019 clean water facilities also have a significant influence on the incidence of diarrhea. The quality of underground water depends on the management of human transport, as well as the physical and chemical characteristics of substances that have a well. Color, smell, taste, $\mathrm{pH}$, turbidity, total coliform and other dissolved ions proved to cause contamination. High turbidity levels due to low air volume in wells. The air volume is less able to cause mud deposits under the surface to be mixed. This can increase the risk of microbial contamination [12].

Many cases of diarrhea caused by people who still used water source from dug wells. The dugs well that did not meet the requirements were a factor in the entry of microbial contamination. The use of drinking water that is not properly cooked and the use of water in washing dishes and bathing is the entry point for the pathogens germs that cause diarrhea. Other things that affect the incidence of diarrhea are latrines. Research conducted by Asnel and Sari states that there is a significant correlation between the use of healthy latrines on the incidence of diarrhea. One of

Table- III: Result of The Multivariate Analysis

\begin{tabular}{|c|c|c|c|c|c|c|}
\hline & \multirow[t]{2}{*}{ B } & \multirow[t]{2}{*}{ Wald } & \multirow[t]{2}{*}{ Sign. } & \multirow[t]{2}{*}{$\begin{array}{c}\text { Exp } \\
\text { (B) }\end{array}$} & \multicolumn{2}{|c|}{$\begin{array}{c}95 \% \text { CI } \\
\text { for } \operatorname{EXP}(\mathrm{B})\end{array}$} \\
\hline & & & & & Lower & Upper \\
\hline Water & 1,542 & 23532 & .000 & 4,67 & 2,50 & 8710 \\
\hline Microbio & & & & 2 & 6 & \\
\hline
\end{tabular}

$\operatorname{logy}(1)$

\begin{tabular}{ccccc}
\hline Constant & -1664 & 41876 & .000 & .189 \\
\hline No. & Water Microbiology & $\begin{array}{c}\text { The formula Y } \\
\alpha+\beta 1 \mathrm{X} 1\end{array}$ & $\begin{array}{c}\text { Probability of } \\
\text { Diarrhea }\end{array}$ \\
\hline
\end{tabular}




\begin{tabular}{cccc}
\hline 1 & TMS & $\begin{array}{l}\mathrm{Y}=-1664+ \\
(1.542 * 1)\end{array}$ & $47 \%$ \\
\hline $\mathbf{2}$ & MS & $\begin{array}{l}\mathrm{Y}=-1654+ \\
(1.542 * 0)\end{array}$ & $18.7 \%$ \\
\hline
\end{tabular}

the criteria for healthy latrines was the distance of a septic tank of more than 10 meters [12].

The quality of latrines has an influence on the incidence of diarrhea. It caused by the lifestyle of people who pay less attention to personal hygiene when they finished defecating, it can contaminate food which will be eaten by them. Beside that, the community have not good enough knowledge about making septic tank that needs a minimum range are $10 \mathrm{~m}$ so it can't contaminate clean water sources.

In this study, SF also influences because SF that is not managed in advance can cause public health and environment problems, which can be a transmission or media for the proliferation of pathogenic microorganisms, causing odors, sources of water pollution, and the spread of diseases caused by various micro-organisms, such as diarrheal diseases [13].

The waste itself in this study did not affect the incidence of diarrhea, because of the many factors that affect the components of the waste to be able to contaminate well water and disrupt the wells. Some of the garbage in the working area of the Northern Territory partly fulfills the requirements, one of which is the cover of garbage, the destruction of garbage by burning, the garbage is not scattered, and the separation of dry and wet waste. Garbage will cause diarrhea only if it is not managed properly. Organic waste that can rot easily can be a media for the nesting of microorganisms to survive, the presence of a pungent odor attracts some vectors of diseases and disruptive animals such as flies. Dangerous diseases such as diarrhea, cholera, typhus, spread quickly in places where waste management is inadequate [13].

\section{CONCLUSION}

Water microbiology is the most influential factor on acute diarrhea incident, with the chance of acute diarrhea in improper dug well water users were 4.67 times higher compared to dug well users with the proper microbiology results. This study showed that counselling about the importance of clean water facilities, latrine, and waste water disposal for living society is needed to prevent acute diarrhea.

\section{ACKNOWLEDGMENT}

We would like to thank the Department of Health of Kediri City and staff and all respondents who have participated in this study who have assisted the implementation of this study.

\section{REFERENCES}

1. R. C. Reiner . (2018). Estimates of The Global, Regional, and National Morbidity, Mortality, and Aetiologies of Diarrhoea in 195 Countries: A Systematic Analysis for The Global Burden of Disease Study 2016. Lancet Infect Disease. 18, pp.1211-1228
Available:https://www.thelancet.com/action/showPdf?pii=S1473-3099 $\% 2818 \% 2930362-1$

2. O. J. Sumampouw, Soemarno, S. Andarini, E. Sriwahyuni. (2015). The Correlation Between Source of Drinking Water And Latrine Existing With Diarrhea Incidence in Manado City. Public Health Research. 5(5), pp.

139-143

Available:http://article.sapub.org/10.5923.j.phr.20150505.03.html

3. H. F. Rahman, S. Widoyo, H. Siswanto, Biantoro. (2016). Factors Related to the Incidence of Diarrhea in Solor Village, Cermee District, Bondowoso. NurseLine Journal. 1(1), pp. 24-35. (in Indonesian) Available:https://media.neliti.com/media/publications/197123-ID-factor s-related-to-diarrhea-in-solor-vil.pdf

4. H. Bhattacharjya, S. K. Das, T. Majumder, B. B. Mukhopadhyay, S. Baidya, D. K. Debbarman. (2017). Bacteriological Quality of Water and Diarrhea Among Ethnic and Non-Ethnic Communities of Rural Area of West Tripura India. International Journal of Research in Medical Sciences. $5(4), \quad$ pp. 1275-1281. Available:https://www.msjonline.org/index.php/ijrms/article/view/2910

5. Z. Ding, Z. Yujia, W. Chen, W. Haocheng, L. Qinbao, L. Junfen, H. Fan. (2017). Infectious Diarrheal Disease Caused by Contaminated Well Water in Chinese Schools: A Systematic Review and Meta-Analysis. Journal of Epidemiology. 27, pp.274-281. Available:https://www.ncbi.nlm.nih.gov/pmc/articles/PMC5463023/pdf /main.pdf

6. E. Engström, B. Balfors, U. Mörtberga, U. Thunvik, T. Gaily, M. Mangold. (2015). Prevalence of Microbiological Contaminants in Groundwater Sources and Risk Factor Assessment in Juba, South Sudan. Science of the Total Environment. 515-516, pp. 181-187. Available:https://www.sciencedirect.com/science/article/pii/S00489697 $1500159 \mathrm{X}$

7. J. V. Megchún-García, C. Landeros-Sánchez., A. Soto-Estrada , M. D. R. Castañeda-Chávez , J. P. Martínez-Dávila, I. Nikolskii-Gavrilov, I. Galaviz-Villa, F. Lango-Reynoso. (2015). Total Coliforms and Escherichia coli in Surface and Subsurface Water from a Sugarcane Agroecosystem in Veracruz, Mexico. Journal of Agricultural Science. 7(6), pp. 110-119. Available:https://www.researchgate.net/publication/276204025_Total_ Coliforms_and_Escherichia_coli_in_Surface_and_Subsurface_Water_f rom_a_Sugarcane_Agroecosystem_in_Veracruz_Mexico

8. Y. Iijima, J. O. Oundo, T. Hibino, S. M. Saidi, A. Hinenoya, K. Osawa, T Shirakawa, R. Osawa, S. Yamasaki. (2017), High Prevalence of Diarrheagenic Escherichia coli among Children with Diarrhea in Kenya Japanese Journal of Infectious Disease.70, pp.80-83. Available:https://www.jstage.jst.go.jp/article/yoken/70/1/70_JJID.2016. 064/_pdf/-char/en

9. J. S. Gruber, A. Ercumen, J. M. Colford. (2014), Coliform Bacteria as Indicators of Diarrheal Risk in Household Drinking Water: Systematic Review and Meta-Analysis. Plos One. 9(9). Available:https://www.ncbi.nlm.nih.gov/pmc/articles/PMC4175079/pdf /pone.0107429.pdf

10. K.Winasari, R. Endriani, F. Chandra, (2015). Bacteriological Test of Drinking Water at the Mount Sikumbang Springs Sarak Island Village Kampar District. JOM FK. 2(2), pp. 1-7. (in Indonesian) Available:https://jom.unri.ac.id/index.php/JOMFDOK/article/view/620 6

11. R. F. Rasako, T. Joko, H. L. Dangiran. (2018). Relationship Between Bacteriological Quality of Dug Well Water and Diarrhea in the Waihaong Village, Ambon City. Jurnal Kesehatan Masyarakat. 6(2), pp. 143-150. (in Indonesian) Available:https://ejournal3.undip.ac.id/index.php/jkm/article/view/2080 9/19520

12. R. Asnel, L. A. Sari. (2019). Correlation Family's Healthy Living Behavior with Diarrhea in Toddlers. KnE Life Sciences. 2019, pp.197-205.

Available:https://knepublishing.com/index.php/KnE-Life/article/view/3 $844 / 8005$

13. L. S. Langit. (2016). Hubungan Kondisi Sanitasi Dasar Rumah dengan Kejadian Diare di Wilayah Kerja Puskesmas Rembang. Jurnal Kesehatan Masyarakat. 4(2), pp. 160-165. Available:https://ejournal3.undip.ac.id/index.php/jkm/article/view/1194 $1 / 11595$ 


\section{AUTHORS PROFILE}

Gita Sekar Prihanti is medical teacher who lead Medical Education Unit (MEU) in Faculty of Medicine University of Muhammadiyah Malang (FM UMM) since 2011 until now.

She completed his bachelor's degree at Brawijaya University in 2006, and postgraduate at Indonesia University in 2011. She already has publications in both national and international journals and proceedings. Gita Sekar Prihanti research interest was in medical education, nutrition and public health.

Syuna Salimdra is instructor in Faculty of Medicine University of Muhammadiyah Malang (FM UMM). 